\title{
Uma missiva contra o peronismo tupiniquim - Carlos Lacerda, Tribuna da Imprensa e a carta Brandi (1955).
}

\author{
A missive against the tupiniquim peronism - Carlos Lacerda, Tribuna \\ da Imprensa and the Brandi letter (1955).
}

\author{
Rodolpho Gauthier Cardoso dos Santos ${ }^{1}$
}

\section{RESUMO}

O artigo analisa um episódio da história política brasileira conhecido como carta Brandi , cuja polêmica se iniciou dias antes das eleições presidenciais de 1955. A principal fonte histórica do trabalho é o diário carioca Tribuna da Imprensa, de propriedade de Carlos Lacerda, então deputado federal pela UDN (União Democrática Nacional). Em setembro daquele ano, o jornal publicou com grande destaque uma carta atribuída ao deputado peronista argentino Antônio Brandi. Ela teria sido enviada a João Goulart, então presidente do PTB (Partido Trabalhista Brasileiro) e candidato à vice-presidência do país na chapa de Juscelino Kubitschek. $O$ controverso conteúdo da missiva, que tratava explicitamente da formação de "brigadas de choque operárias" e da compra de mercadorias na Fábrica Militar de Córdoba, tumultuou o processo eleitoral. Políticos e jornais conservadores alegaram que a eleição do líder trabal hista levaria o país a uma ditadura com apoio argentino. Analisa-se aqui a atuação de Tribuna da Imprensa e de seu proprietário nesse momento político convulsionado, marcado pelo forte imaginário antiperonista.

Palavras-chave: : Política. Imprensa. Conservadorismo. Antiperonismo.

\section{ABSTRACT}

This article analyses an episode of the Political History of Brazil known as Brandi letter, which controversy occurred some days before the 1955's Brazilian election for president. The main historical source of this paper is the carioca newspaper Tribuna da Imprensa, whose ownership was in the hands of Carlos Lacerda, federal deputy from UDN (União Democrática Nacional). In September of that year, this newspaper scandalously published a letter attributed to an argentinian peronist deputy named Antonio Brandi. The message would have been sent to João Goulart that was by that time the president of the PTB (Partido Trabal hista Brasileiro) and a candidate for the vice-presidency with the support of Juscelino Kubitschek. The controversial content of the letter, which explicitly tells about the formation of "brigades of shock

\footnotetext{
${ }^{1}$ Doutor em História Social (USP, 2015). Professor do Instituto Federal de Minas Gerais(IFMG), campus Ouro Branco. Este artigo apresenta parte dos resultados da pesquisa de doutorado com modificações e ampliação do texto realizados após a defesa. E-mail do autor: rodolpho.santos@ifmg.edu.br
} 
workers" and the acquisition of products from Cordoba's military factory, disrupted the electoral process. Politicians and conservative newspaper alleged that the election of the trabalhista leader would carry the country to a dictatorship with the Argentinian support. This academic work analyses the agency of Tribuna da Imprensa and of his owner in this convulsed moment of Brazilian politics, in which the antiperonist imaginary was very strong.

Keyword: Politics. Press. Conservatism. Antiperonism.

\section{Carlos Lacerda e Tribuna da Imprensa}

Filho de um deputado federal de tendências esquerdistas, Carlos Lacerda (1914-1977) nasceu em Vassouras, estado do Rio de Janeiro, e foi batizado Carlos Frederico Werneck de Lacerda, com os dois primeiros nomes em homenagem a Karl Marx e Friedrich Engels (MENDONÇA, 2002, p. 21). Na juventude, militou no Partido Comunista do Brasil (PCB) e integrou a Aliança Nacional Libertadora (ANL), o que o levou a ser preso em algumas ocasiões por participar de atividades tidas como subversivas.

A partir de 1938, dedicou-se a atividades jornalísticas, especialmente em $O$ Jornal, matutino carioca que pertencia ao poderoso empresário da comunicação Assis Chateaubriand. No ano seguinte, veio o traumático rompimento com a esquerda, após a ssinar um artigo profundamente anticomunista encomendado pelo Departamento de Imprensa $e$ Propaganda (DIP). Expulso do PCB e tido como traidor, Lacerda perdeu muitos de seus antigos amigos, o que ajuda a entender seu gradual deslocamento para o lado oposto do espectro político (MENDONÇA, 2002, p. 51-61).

Já filiado à UDN (União Democrática Nacional) e conhecido no circuito jornalístico da capital federal, Lacerda passou a assinar, a partir de 1946, a coluna "Na Tribuna da Imprensa", publicada no diário Correio da Manhã. Dono de uma retórica envolvente e agressiva, Lacerda, que se tornara um ferrenho antigetulista e anticomunista, defendia enfaticamente a entrada do capital internacional e o alinhamento geopolítico do Brasil aos Estados Unidos. É desse período sua conversão ao catolicismo e uma crescente popularidade, especialmente entre as classes alta e média, o que o levou a um breve mandato como vereador no Rio de Janeiro, em 1947. Após romper com Paulo Bittencourt, dono do diário carioca em que trabalhava, Lacerda fundou seu próprio jornal, conservando o título da coluna que o tornara conhecido.

Tribuna da Imprensa teve seu primeiro número publicado em 27 de dezembro de 1949. Na versão de seu proprietário, o jornal vespertino teria nascido de uma campanha organizada por seus amigos, que angariou acionistas desejosos de "dispor de um veículo de comunicação 
que fosse, acima de tudo, imparcial e dissesse a verdade". Embora Lacerda insistisse no caráter popular dos fundos, a historiadora Marina Gusmão de Mendonça apontou o contrário. Segundo a autora, o mais provável é que o periódico tenha surgido a partir de "grupos empresariais vinculados ao capital externo". De acordo com ela,

[...] o simples exame da relação dos maiores acionistas corrobora essa tese, bem como a constatação de que, entre os principais organizadores e, posteriormente, dirigentes da empresa, estavam figuras de proa do empresariado, com notórias vinculações externas, ou, ao menos, pessoas que com esses grupos mantinham estreitas ligações. (MENDONÇA, 2002, p. 101-102).

Ainda que fosse influente e incomodasse os adversários, o "jornal do Lacerda"2 nunca atingiu grandes tiragens. Isso não impediu que o diário se configurasse em uma excelente plataforma política, que garantiu ao seu proprietário popularidade cada vez maior.

Ao analisar os editoriais de Lacerda, Mendonça (2002, p. 12) apontou uma constante tentativa de automitificação que se manifestava na construção da "imagem de homem providencial, a do herói encarregado de salvar a pátria ameaçada". Essa autoimagem se coadunava com a insistente denúncia maniqueísta de que o povo estava sendo continuamente explorado por vilões corruptos. Segundo o jornalista fluminense, entre os inimigos que personificavam o mal a ser combatido estariam, a variar conforme o contexto, os trabalhistas (ou "gregórios"3), os peronistas e, principalmente, os comunistas, adversários bem conhecidos e apontados eterna mente como culpados pelos males que ameaçavam o país. A salvação dos valores tradicionais, segundo Lacerda, passaria pela organização e atuação de homens racionalmente superiores, paladinos da moralidade, pessoas com abnegada atuação, capazes de se manterem impolutos em nome do amor à pátria.

Tal retórica, que encontrava em Lacerda um de seus principais expoentes, integrava, de modo geral, o discurso da UDN. Criada nos meses finais do Estado Novo como um partido que

\footnotetext{
${ }^{2}$ Esse personalismo foi corroborado por depoimentos do período. Aluísio Alves, então redator-chefe do periódico, relatou certa vez que uma das dificuldades do cotidiano era o "método de Lacerda, que participava de tudo, escrevia do seu artigo à pequenas notas, acompanhava todas as seções do jornal, orientava, reclamava, modificava, numa velocidade de trabalho difícil de acompanhar"(Apud RIBEIRO, 2007, p. 148).

${ }^{3}$ Termo de conotação pejorativa utilizado após a crise de agosto de 1954 para definir os adeptos do varguismo. Ele faz referência a Gregório Fortunato, chefe da guarda pessoal de Vargas e condenado como mandante do atentado da rua Tonelero, no Rio de Janeiro em 1954, que culminou no ferimento de Carlos Lacerda e na morte do major-aviador Rubens Vaz.
} 
bradava pela democracia, ela congregou, inicialmente, líderes com ideologias diversas, quando não antagônicas. Posteriormente, o desenrolar dos anos e das contendas eleitorais conferiu à agremiação um viés cada vez mais moralista e elitista.

Para a socióloga Maria Victoria de Mesquita Benevides (1981, p. 224), a identidade da agremiação se baseava, entre outras coisas, na "autoestima, reforçada pela crença na 'qualidade superior' de seus dirigentes". A autoimagem da excelência de seus quadros levou o partido a se colocar com frequência como um "pedaço de chão limpo", decente e digno em relação aos demais. Essa ideia de "partido incorruptível" era reforçada pela atuação parlamentar centrada nas constantes denúncias de desvios administrativos, de subversão da ordem provocada pelas políticas trabalhistas e da suposta infiltração comunista na sociedade. Não sem razão, o símbolo da UDN era a tocha olímpica com uma labareda, abaixo da qual constava o lema paranoico: "o preço da liberdade é a eterna vigilância" (BENEVIDES, 1981, p. $172,212,268)$.

De modo geral, identificavam-se as reivindicações sociais de comunistas e getulistas como agitações que ameaçavam o status quo. Nesse sentido, emanava de muitos discursos udenistas o "temor onipresente à desordem", à anarquia que supostamente adviria com a "ascensão das massas ignorantes".

As sucessivas derrotas nas eleições presidenciais de 1945, 1950 e 1955 reforçaram em muitos de seus membros a ideia de que era necessária uma "democracia tutelada", pois "o povo não sabe votar". Ou seja, não estaria preparado para usufruir a liberdade. Essa noção justificava os constantes apelos à intervenção militar contra um sistema político considerado "ilegítimo porque tolera (e até estimula) manifestações de grupos sociais incompatíveis com a ordem desejada". Em consequência desse raciocínio, defendia-se que "o golpe é legítimo porque quer destruir um sistema ilegítimo" ou, nas palavras de Carlos Lacerda, de que seria necessário "defender o golpe para evitar o golpe por via eleitoral" (BENEVIDES, 1981, p. 254, 263).

Embora alguns de seus membros apoiassem ideias autoritárias, a UDN não pode ser considerada um partido de inspiração fascista. A agremiação enfatizava a importância da liberdade e da democracia, ainda que controlada e restrita. Nesse sentido, mesmo udenistas abertamente golpistas, como Lacerda, defendiam regimes autoritários apenas transitórios, capazes de "limpar" o terreno para a construção de uma suposta "democracia verdadeira", sem "agitadores" e "subversivos". Ou seja, advogavam uma espécie de "ditadura educativa" (BENEVIDES, 1981, p. 255).

É importante destacar também que as ideias de Lacerda não representavam a UDN em sua totalidade. Avesso à disciplina partidária, o jornalista tinha atuação bastante personalista e chegou a criticar abertamente alguns colegas correligionários. 
Certo é que, mesmo sem exercer mandato político no período entre 1951 e 1954, Lacerda transformou-se, aos poucos, em um dos principais e mais intransigentes líderes da oposição udenista ao governo Vargas. Nesses anos, ele soube capitalizar politicamente o espaço franqueado por Roberto Marinho em sua rádio e por Assis Chateaubriand na TV Tupi.

Em relação ao antiperonismo, o jornalista e Tribuna da Imprensa tiveram uma atuação bastante destacada. Lacerda apontava com frequência semelhanças entre Vargas e Perón. Afirmava que eram líderes demagógicos e autoritários que representariam um grande perigo para a democracia brasileira. Na sua visão, os petebistas representariam uma espécie de "peronismo indígena" (Tribuna da Imprensa, 9 dez. 1954, p. 1)

O coronel Juan Domingo Perón (1895-1974) destacou-se inicialmente como parte de um grupo autoritário e, em grande medida, conservador que deu um golpe de Estado na Argentina em 1943. Durante a ditadura do Grupo de Oficiales Unidos (GOU), ele ocupou os cargos de vice-presidente, Ministro da Guerra e Secretário do Trabalho. Foi nesta última função que adotou políticas favoráveis aos trabalhadores que se assemelhavam às de Vargas, político que afirmou repetidas vezes admirar. ${ }^{4}$ Com apoio dos sindicatos, do Exército e da Igreja Católica, foi eleito presidente democraticamente em 1945 e reeleito em 1951.

Durante seu governo, desenvolveu-se uma forte política de distribuição de renda e de intervenção do Estado na economia, incluindo a nacionalização de ferrovias e serviços. Em relação à política externa, o regime peronista declarou a terceira posição durante a Guerra Fria (CAVLAK, 2008). Não buscaria o capitalismo e tampouco o comunismo, mas aquilo que Perón chamou de justicialismo. ${ }^{5}$ Também são características desse período a construção de uma ampla e bem articulada estrutura de propaganda oficialista, que incluía controle sobre grande número de meios de comunicação, e um crescente autoritarismo, que resultou em perseguições e prisões de antiperonistas além do fechamento arbitrário de dezenas de jornais vinculados à oposição (CAPELATO, 2008).

Durante as eleições presidenciais brasileiras de 1950, boatos a respeito de apoio financeiro peronista à campanha de Vargas foram publicados em diversos jornais nacionais de oposição ao getulismo. Em Buenos Aires, a imprensa portenha controlada pelo governo fez intensa campanha a favor do candidato gaúcho (CAVLAK, 2008, p. 56-57). Meses antes das eleições presidenciais de 1950, Carlos Lacerda (Tribuna da Imprensa, 10 ago.1950, p. 4) já afirmava em editorial: "Perón está profundamente ligado ao destino do movimento do sr. Getúlio Vargas". E acrescentou:

\footnotetext{
${ }^{4}$ Estabeleceu, entre outras medidas, férias remuneradas e o aguinaldo, remuneração extra no final do ano (equivalente ao $13^{\circ}$ salário no Brasil).

${ }^{5}$ Perón dizia, em seus discursos, que sua ideologia não era capitalista ou comunista, mas justicialista, por enfatizar a busca da justiça social. Tal qual Vargas, costumava lembrar aos empresários que as medidas de cunho social tomadas pelo Estado eram a melhor forma de evitar a repetição dos acontecimentos russos de 1917.
} 
A tolerância para com o sr. Getúlio Vargas, neste momento, significa a condescendência com um cúmplice de Perón. É preciso não esquecer que assim como Perón aprendeu com a ditadura do sr. Getúlio Vargas este modernizou muito o seu estilo ditatorial com as lições que lhe deu o marido da incandescente panfletária de Buenos Aires.

O sr. Getúlio Vargas encarna o peronismo no Brasil [...]

As urnas, porém, sufragaram Vargas em 1950. Os boatos sobre uma aliança secreta entre trabalhistas e justicialistas continuaram nos anos seguintes e se avolumaram principalmente a partir da indicação de João Goulart para Ministro do Trabalho, Indústria e Comércio, em junho de 1953. Jornais conservadores como Tribuna da Imprensa difundiram à exaustão a ideia de que esse jovem e popular líder estaria se aproximando dos sindicatos para construir uma base eleitoral que ampliasse o poder dos trabalhistas no Congresso. Assim, seria possível reformar a Constituição, criar a possibilidade de reeleição ilimitada e garantir a continuidade do grupo no palácio do Catete. Grosso modo, seria essa a estratégia dos líderes do PTB para criar uma suposta "república sindicalista". Tal expressão foi muito utilizada pela oposição para imputar aos trabalhistas um projeto político autoritário - a criação de regime discricionário baseado nos sindicatos semelhante àquele que, alegavam, já existia na Argentina.

O ponto alto das denúncias envolvendo o peronismo ocorreu em março de 1954, quando Tribuna da Imprensa divulgou, em primeira mão, um discurso reservado de Perón. Nele, o presidente argentino afirmava ter tido conversas secretas com Vargas, por meio de intermediários, no intuito de estabelecer o Pacto $A B C$, acordo econômico composto por Argentina, Brasile Chile. O chefe da Casa Rosada acrescentou que Vargas lhe dera o direito de representar os interesses do Brasil nas negociações com o Chile. O Pacto ABC, ideia difundida pela diplomacia justicialista, vinha sendo fortemente rejeitado por políticos e jornalistas oposicionistas brasileiros, que viam na proposta uma artimanha argentina para esconder seu imperialismo e sua vontade de, inspirada na atuação de Juan Manuel de Rosas (1793-1877), dominar a região e restabelecer as fronteiras coloniais que compunham o vice-reinado do Rio da Prata.

Embora a autenticidade do discurso de Perón tenha à época sido negada pelo governo platino, o presidente brasileiro passou a ser acusado de firmar acordos sigilosos com a 
Argentina sem o consentimento do Congresso. ${ }^{6}$ Essa acusação, junto com a de improbidade administrativa e crimes de responsabilidade ligados à má execução orçamentária, deu origem a um processo de impeachment de Vargas, que se desenrolou a partir de maio de 1954. Em 16 de junho, o pedido foi rejeitado pela maioria dos deputados. Salvo, o governo ficou ainda mais desgastado e, como se sabe, terminou de maneira trágica apenas dois meses depois.

\section{A carta Brandi}

A forte comoção que se seguiu à morte de Vargas demonstrou a popularidade do presidente falecido. Além disso, constrangeu temporariamente os adeptos civis e militares da intervenção armada, muitos dos quais tinham exigido sua renúncia. Horas após o suicídio, o país passou a ser comandado por João Café Filho, vice-presidente de ideias conservadoras.

Lacerda, no entanto, colheu os frutos da forte polarização que acometeu o país. Em eleições realizadas apenas quarenta dias após a morte do político gaúcho, foi eleito deputado federal com o maior número de votos do Distrito Federal.

No início do ano seguinte, o presidente Café Filho demonstrou publicamente sua proximidade com a nova cúpula militar, formada, em sua maioria, por antigetulistas. Estes defendiam o lançamento de um candidato civil de "união nacional" em chapa única para as eleições presidenciais a serem realizadas em outubro. Mesmo com apoio do presidente, a ideia não encontrou eco nos outros partidos. Em fevereiro, o PSD (Partido Social Democrático) confirmou a candidatura do governador de Minas Gerais, Juscelino Kubitschek. Em abril, um acordo garantiu a vice-presidência da chapa ao PTB, que indicou João Goulart.

A aliança imediatamente alarmou os setores antigetulistas, que continuavam organizados depois de agosto de 1954. Temendo uma terceira derrota eleitoral consecutiva da UDN, Lacerda e outros correligionários mais radicais passaram a conclamar por um governo de emergência que suspendesse a Constituição, impedisse as eleições e fizesse uma "reforma da democracia brasileira para instaurar a legalidade legítima" (LACERDA apud SKIDMORE, 1982, p.185). Tratava-se de um eufemismo para a palavra golpe.

Pouco depois, a UDN lançou como candidato o general cearense Juarez Távora, chefe da Casa Civil do governo Café Filho e que participara das articulações para tirar Vargas do poder

${ }^{6}$ Confirmou-se anos depois que o discurso secreto de Perón era verdadeiro (PERÓN, 1968). Seu conteúdo, porém, ainda é alvo de controvérsias. Vargas e assessores próximos negaram diversas vezes a versão contada pelo presidente argentino naquela palestra reservada. 
no ano anterior. $O$ escolhido, porém, carecia do carisma e do otimismo que abundavam no concorrente mineiro.

Temerosa, parte da imprensa conservadora passou a atacar violentamente a fórmula J-J (Juscelino e Jango), com acusações que evocavam a insistente representação (CHARTIER, 1991) de uma conspiração para implantar uma "república sindicalista". Alegava-se constantemente também que o candidato à vice-presidente era um peronista.

Em junho, Tribuna da Imprensa (8 jun. 1955) noticiou, em primeira página, a existência de "rumores" e "informações não documentadas" sobre tráfico de armas na fronteira entre Brasil e Argentina, especialmente na região de São Borja, onde vivia o ex-ministro de Vargas, João Batista Lusardo. Em agosto, a edição do dia 12 teve como manchete principal: "Jango prepara a guerra civil". Sem citar fontes, o texto, que tampouco trazia assinatura, assegurava que Jango havia retomado seus contatos com Perón e iniciado a importação secreta de armas e munição da Argentina. Sua candidatura à vice-presidência contaria com a "assistência técnica" dos justicialistas e apoio dos comunistas, que teriam recebido uma quantia vultosa para ampará-lo.

Um mês antes das eleições, o líder comunista Luís Carlos Prestes, cujos direitos políticos estavam proscritos, fez um comunicado conclamando seus correligionários a votarem em Goulart e Kubistchek, o que ampliou também as recorrentes acusações de um conluio entre petebistas e vermelhos (DULLES, 1992, p.219). Cientes dos problemas causados pelo apoio, a chapa J-J negou publicamente um aliança secreta com os comunistas (CARLONI, 2014, p. 114).

Figura 1 - Jango prepara a guerra civil.

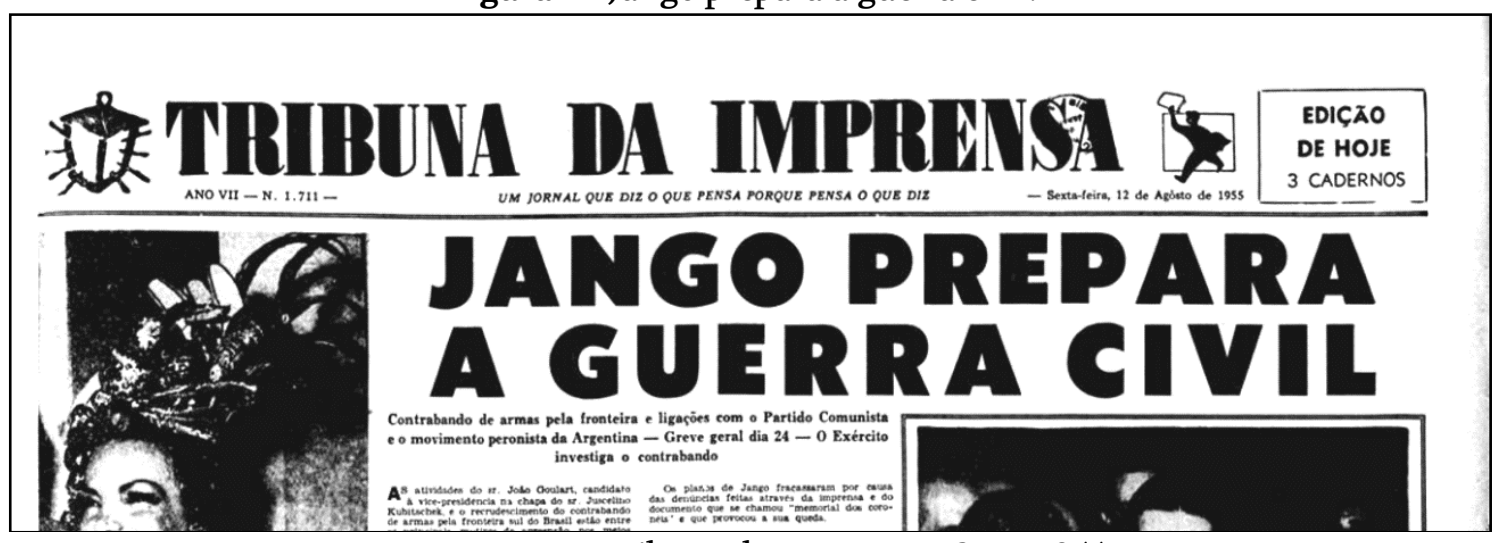

Fonte: Tribuna da Imprensa, 12 ago.1955.

Exatos dezessete dias antes das eleições, Lacerda exibiu na TV-Rio um documento que supostamente comprovaria as relações entre o candidato à vice-presidência e o regime argentino. A cobertura da novidade foi feita por Tribuna de Imprensa (17-18 set. 1955, p. 1, 4) que, 
no dia seguinte, anunciou em primeira mão e com estardalhaço: "Eis a prova da traição de Jango". Na ocasião, o diário apresentou uma suposta carta em espanhol do deputado provincial peronista Antônio Jesus Brandi para João Goulart. A missiva estava datada de 5 de agosto de 1953, período em que este era ministro do Trabalho. De acordo com o jornal, o documento teria sido apreendido em um hotel do Rio de Janeiro, quando ali estivera seu portador, o comerciante argentino Ignacio Pinedo. Não havia informação sobre quem havia realizado a suposta apreensão.

Na polêmica carta, que possuía timbre da Câmara dos Deputados da província de Corrientes, Brandi informava a Goulart sobre a entrega confidencial de "protocolos e recomendações sobre 'brigadas de choque operárias", enviados pelo justicialista Ángel Borlenghi, ministro do Interior. Este acreditava que seria útil a Goulart "aproveitar a experiência obtida na luta sindical argentina". O documento comunicava também que o vicegovernador da província de Corrientes, Clementino Forte, havia sido "designado para dirigir todas as atividades de coordenação sindical entre Brasil e Argentina”. Por fim, confirmava-se a compra de "mercadoria" na "Fábrica Militar de Córdoba", que chegaria ao Brasil via Uruguaiana "disfarçada de produtos alimentícios". 
Figura 2 - Fac-símile da carta Brandi publicada em Tribuna da Imprensa

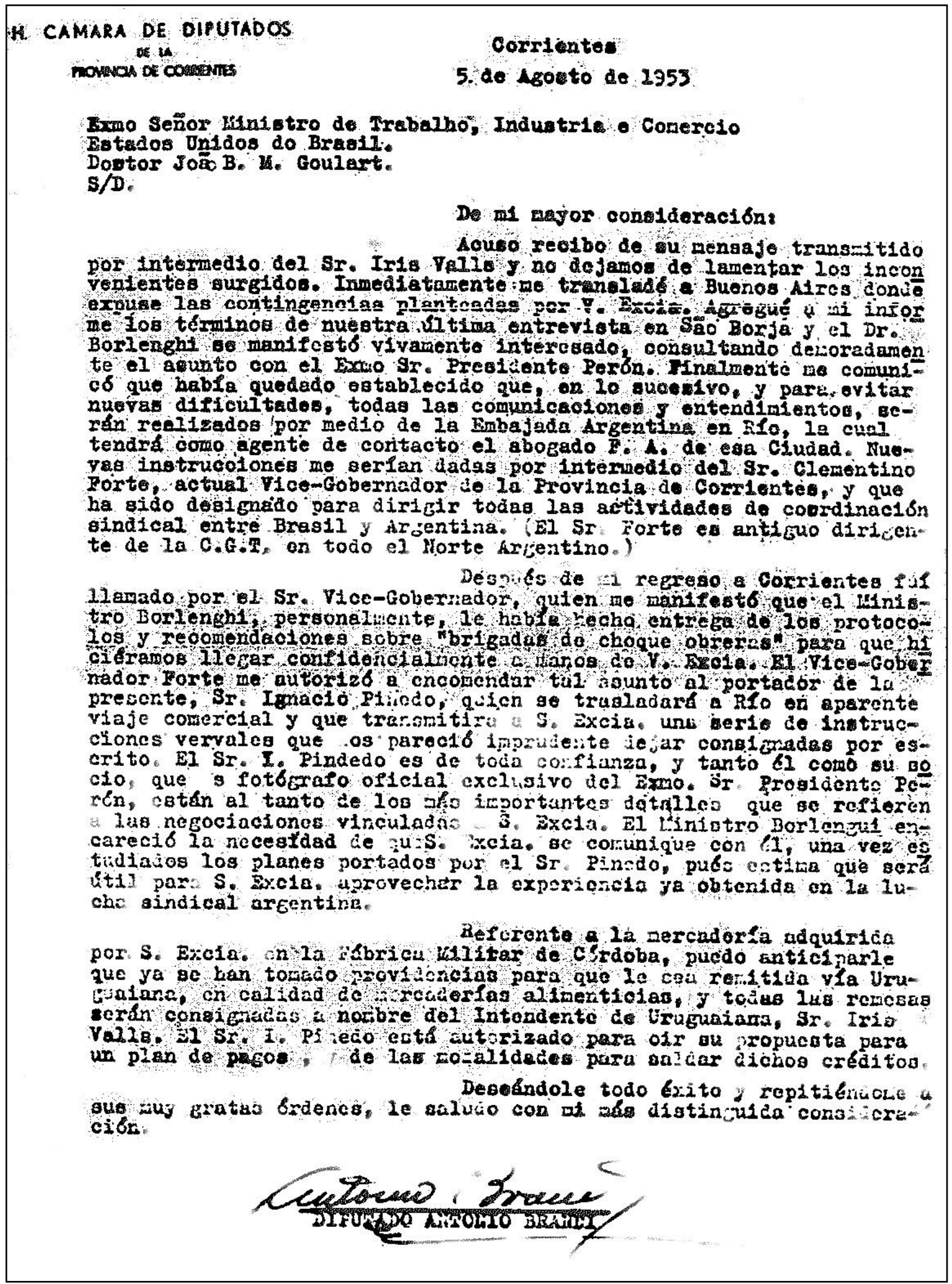

Fonte: Tribuna da Imprensa, 17-18 set. 1955, p. 1. 
Na televisão, Lacerda (Tribuna da Imprensa, 17-18 set. 1955, p. 4) assegurou: "Só trouxe esta carta ao conhecimento público quando me convenci da sua autenticidade". Em seguida, bradou:

Depois de um documento desses, que mais se pode dizer?

Teremos uma eleição a 3 de outubro e o candidato franco favorito à vicepresidência da República é um homem ligado à quinta-coluna comunista no Brasil.

Como se isso não bastasse tem-se agora a prova evidente da submissão de Jango Goulart a Perón. Será preciso acrescentar mais alguma coisa?

Vamos nos conformar a ver o Brasil governado por conta e ordem de Perón?

[...] Não quero ditadura para o Brasil. Mas acho que a crise brasileira exige uma reforma de estrutura completa e urgente que reestabeleça a confiança do povo, criando condições para a democracia no Brasil.

Essa reforma é indispensável e pode ser obtida, dentre outras maneiras, por uma solução extralegal. A ilegalidade em tempo de crise não é a mesma ilegalidade dos tempos normais.

Reivindico plenos poderes para que o governo, durante determinado tempo, execute determinadas tarefas [...]

Vamos permitir a infiltração comunista e peronista em nosso país, através do próprio vice-presidente da República?

Vamos entregar o Brasil de graça a Perón? Só para que haja eleições? Na Hungria e na Polônia também houve eleições. Nem por isso se impediu que os comunistas tomassem conta desses países.

A denúncia caiu como uma luva sobre os boatos de tráfico de armas na fronteira argentina que vinham sendo publicados há meses. Coincidentemente, no mesmo dia em que a carta Brandi foi divulgada na TV, o regime peronista foi derrubado por um movimento militar que culminou na fuga de Perón para o Paraguai. Tribuna da Imprensa (17-18 set. 1955, p. 1) imediatamente saudou a novidade e noticiou: "Constituído o governo da revolução argentina". 
Isso, porém, não aplacou a polêmica sobre a suposta colaboração armada recebida do regime peronista. A pedido de parlamentares do próprio PTB, foi criado nos dias seguintes um inquérito policial militar (IPM) para apurar a autenticidade do documento. A iniciativa esteve sob responsabilidade do general Emílio Maurell Filho, secretário geral do Ministério da Guerra. Nesse ínterim, aliados de João Goulart levantaram muitas dúvidas sobre o documento, a começar pela sua origem. Desde o início, Lacerda protegeu suas fontes e não esclareceu de que modo o obtivera. Alegou simplesmente que ele fora apreendido, sem dizer por quem.

Outras objeções levaram em conta diversos aspectos internos da missiva, que, apesar de supostamente secreta, apresentava conteúdo puerilmente explícito em relação às atividades criminosas. Chamava atenção que apenas um dos indivíduos citados tenha sido poupado, ao ser mencionado pelas iniciais. Todos os outros tiveram seus nomes abertamente apresentados. Com efeito, o conteúdo excessivamente compreensivo soou como uma tentativa deliberada de comprometer os citados, especialmente João Goulart.

Estranhou-se também a grafia correta de palavras como "João" e "São", pois nas máquinas de escrever em língua espanhola predomina o til em uma única tecla, o " $\tilde{\mathrm{n}}$ ". Tribuna da Imprensa (23 set. 1955, p. 1) redarguiu mostrando uma máquina usa da nos países vizinhos em que o til aparecia isolado em uma única tecla, separada do "n". O jornal tripudiou: "Vai mal o sr. Juan [sic] Goulart se confia apenas nesse til para salvar-se".

Havia ainda outros erros ortográficos que levantaram a desconfiança de que o documento possivelmente fora escrito por um lusófono. Ao invés de "trasladé", grafia correta em espanhol, constava a palavra "transladé". "Pues" aparece com um estranho acento: "pués". E o nome do ministro do Interior, Ángel Borlenghi, foi grafado uma vez como "Borlengui". Igualmente, parecia muito suspeito que algo tão comprometedor para Jango, datado de agosto de 1953, viesse a público pouco mais de duas semanas antes das eleições nas quais ele era favorito.

À sua maneira, Lacerda (Tribuna da Imprensa, 23 set. 1955, p. 4) buscou rebater cada um dos pontos levantados e definiu os argumentos dos adversários como "torcicolos, são contorções da verdade para esconder o medo, o grande medo de que estão possuídos". Em defesa da carta, o jornalista João Duarte Filho (Tribuna da Imprensa, 23 set. 1955, p. 3) argumentou que Brandi, como correntino, era um personagem fronteiriço, que poderia inconscientemente ter usado a linguagem híbrida que predominaria na região. Além disso, em sua perspectiva, apenas um argentino cometeria tais erros ao escrever despreocupadamente, pois um estrangeiro estaria sempre alerta com uma língua que não é a sua. Para Lacerda (Tribuna da Imprensa, 29 set. 1955, p. 4), era um absurdo "exigir de um pobre deputado provincial, e ainda por cima peronista, que escreva segundo os moldes clássicos da Espanha". 
Com as muitas dúvidas levantadas em relação à carta Brandi, alguns udenistas acreditavam que apenas uma confirmação cabal poderia mudar o cenário de favoritismo da chapa PSD-PTB. Assim, paralelamente à investigação oficial, Lacerda embarcou para Buenos Aires. Na ocasião, atacou (Tribuna da Imprensa, 23 set. 1955, p. 1): "Jango ia buscar em Buenos Aires armas para a guerra civil. Nós vamos a Buenos Aires tentar obter mais munição para a vitória de Juarez nas eleições". E aduziu que perseguiria "as provas da traição dos candidatos peronistas, mancomunados com a corrupção e o comunismo [...]".

Na capital argentina, Lacerda conseguiu localizar Ignacio Pinedo, suposto portador da carta secreta. Embora ele negasse qualquer participação nos acontecimentos, admitiu que Brandi era padrinho de um de seus filhos e que conhecia Jango desde menino, embora não fosse seu amigo íntimo. Forneceu também um documento com assinatura do deputado correntino, que pareceu aos olhos de Lacerda de "impressionante identidade" com a que constava na controversa missiva. Foi o suficiente para que o jornal(Tribuna da Imprensa, 26 set. 1955, p. 1) apressadamente estampasse em letras garrafais: "A Tribuna tem as provas da traição de Jango ao Brasil".

Como era de se esperar, Última Hora, principal jornal vinculado ao varguismo, imediatamente lançou suspeitas em relação à carta Brandi. Diários cariocas de oposição ao trabalhismo, mas defensores da legalidade, também pareciam duvidar da sua autenticidade. Matutinos como O Jornal, de Assis Chateaubriand, e Correio da Manhã, de Paulo Bittencourt, mobilizaram seus repórteres para conseguir mais informações sobre o caso. Dias depois, Lacerda (Tribuna da Imprensa, 29 set. 1955, p. 4) passou a utilizar a expressão "imprensa perono-janguista" para se referir àqueles que colocavam o documento em dúvida.

A quatro dias do pleito, o jornalista fluminense assegurou em editorial Lacerda que apenas a vitória de Juarez Távora (UDN) e de seu vice, Milton Campos, seriam capazes de realizar "a extirpação do peronismo no Brasil". Tribuna da Imprensa (29 set. 1955, p. 4) também reproduziu um discurso de Lacerda proferido na Câmara dos Deputados em que ele exortou os brasileiros a "mirar-se no espelho despedaçado da Argentina peronizada para compreender quão perto esteve [o Brasil] dessa desgraça e quanto dela se aproximará de novo se não optar na hora exata, com o sentido de gravidade da decisão de cada qual, neste momento da vida brasileira".

Lacerda (Tribuna da Imprensa, 30 set. 1955, p. 4) provavelmente já intuía a possibilidade da derrota eleitoral e alegou que estavam para acontecer no Brasil eleições ilegítima s, "parecidas com as que se realizavam na Argentina, durante Perón". No editorial publicado no domingo de eleições (Tribuna da Imprensa, 3 out. 1955, p. 1) foi ainda mais explícito em relação a isso. Em aberta pregação golpista, defendeu que o pleito só deveria ocorrer após a "desintoxicação do país": 
PESA sobre o país, no dia de hoje, a ameaça de voltar a um passado de desonra, de manobras inconfessáveis, de corrupção desalmada.

O comício de Kubitschek e Jango foi uma exibição indecorosa desse conluio já agora exposto com insolência, das forças mais detestáveis: o peronismo, com Jango Goulart e seus contrabandistas, o comunismo, revolvendo a vasa social para esculpir a estátua de Kubitschek, o negocismo, preparando o seu retorno triunfal [...].

As eleições vão ser fartamente roubadas. Roubadas em si mesmas, roubadas antes de serem feitas, roubadas na apuração. É fraude, e da pior, permitir que concorram às eleições candidatos sabidamente incapacitados, sob o ponto de vista da moral pública, de exercerem os cargos para os quais pleiteiam o voto popular [...] Sustentamos que era preciso, primeiro, desintoxicar o país, promover a reforma de certas leis fundamentais, a revisão do registro eleitoral, etc., para depois convocar eleições [...].

Coincidentemente, um fato novo apareceu justamente no dia do pleito. Enquanto os brasileiros formavam longas filas nos postos de votação, Lacerda, usando os microfones da Rádio Globo, no Rio de Janeiro, transmitiu informações de um telegrama oriundo de Buenos Aires. Em pleno domingo eleitoral, a nota anunciava que um laudo pericial da Polícia Federal argentina, obtido pelo inquérito do general Emílio Maurell Filho, admitira ser "sumamente provável" a autenticidade da assinatura que constava na carta Brandi. Contrariando a legislação eleitoral, que proibia propaganda 48 horas antes do pleito, o jornalista fluminense (Tribuna da Imprensa, 4 out. 1955, p. 1, 8) celebrou entusiasticamente a novidade:

Não estou aqui para fazer propaganda eleitoral. Vim aqui para congratular-me com a Nação brasileira pela descoberta, pela comprovação da autenticidade da prova da traição contra ela cometida por determinados indivíduos [...].

É por nossos filhos, é por nossa gente, é por nossa terra, que eu venho à Rádio Globo, congratular-me com a Nação brasileira, com o povo brasileiro e agradecer a Deus, numa prece fervente, pela misericórdia que nos fez, pela graça que nos deu, proporcionando ao Brasil esta oportunidade - talvez única e talvez mesmo derradeira - de comprovar a traição contra ele longamente premeditada e demoradamente 
consumada e que agora, ainda a tempo, se pode contrarrestar e inutilizar, através da consciência, através dos atos conscientes, através das ações lúcidas patrióticas e inspiradas na misericórdia de Deus para com os filhos desta grande Pátria.

Indagado sobre as implicações da publicação do laudo naquele momento político delicado, o ministro da Guerra, Henrique Teixeira Lott, absteve-se de comentar. Tribuna da Imprensa (7 out. 1955, p. 1) defendeu sua atitude: "Este é um país em que os homens de bem cumprem os seus compromissos: mesmo o de empossar no Governo um traidor da Pátria".

Seguiram-se protestos por parte do PTB e do PSD, alegando que a legislação eleitoral havia sido ferida. Em resposta, na Rádio Globo, Lacerda (Tribuna da Imprensa, 4 out. 1955, p.4) destacou que, caso houvesse cometido crime eleitoral, "renunciaria às suas imunidades e pagaria gostosamente os 15 dias de prisão estabelecidos pela lei, uma vez que trouxera ao conhecimento do Brasil fatos importantes sobre a traição" que importavam mais do que uma "discussão bizantina" como aquela. Em um texto não assinado, intitulado "Muito barulho por nada", Tribuna da Imprensa (4 out. 1955, p.1) redarguiu: "A Rádio Globo concitou seus ouvintes a votar contra a corrupção e a ameaça comunista. O PSD e o PTB, protestando contra esse fato, revelaram que a carapuça caía em suas cabeças, ao alegar que essa irradiação prejudicava a Juscelino e a Jango".

No dia seguinte à eleição, outro artigo não assinado resumiu com riqueza de detalhes o "mito da conspiração", para usar uma expressão do historiador francês Raoul Girardet (1987), que vinha se desenvolvendo na imprensa conservadora há anos. $O$ texto não deixava claras as fontes das informações e misturava dados concretos com boatos para compor uma história aparentemente coerente. De acordo com o artigo, a "traição" dos trabalhistas se iniciara após as eleições presidenciais de 1950, diante da possibilidade de o Tribunal Superior Eleitoral acatar o argumento udenista de que Vargas não obtivera maioria absoluta no pleito. Caso a posse fosse impugnada, o político gaúcho sublevaria as tropas da $3^{\text {a }}$ e da $5^{\text {a }}$ região militar e transferiria a capital do país para Porto Alegre, onde instalaria o novo ministério. Sob comando de Jango, teria sido estabelecida uma aliança com Perón, que reconheceria imediatamente o novo governo e disponibilizaria tropas para ajudar na marcha armada a téo Rio de Janeiro. Embora tal ação militar não tenha sido necessária, os dois presidentes teriam criado laços que se mantiveram nos anos seguintes. Em 1953, Jango teria sido nomeado ministro do Trabalho justamente por pressão de Perón, que buscava intensificar suas relações com o Brasil. Na conclusão, destacou-se os encontros frequentes em Buenos Aires em que o chefe da Casa Rosada "recebia o emissário [Jango] amiúde e com ele sonhava o advento de um novo Rosas, ressuscitado nas águas do Prata para o trono de um vice-reinado que atingia as fronteiras de uma alucinação" (Tribuna da Imprensa, 4 out. 1955, p. 2). 
Dias depois, dando seguimento às teorias conspiratórias, Tribuna da Imprensa (17 out. 1955, p.1) publicou na sua primeira página mais um artigo sem assinatura intitulado "Peronismo, perigo imediato para o Brasil". Nele, lia-se: "a guerra pela restauração do peronismo na Argentina será tecida, preparada, mobilizada no Brasil" imediatamente após a chegada de Goulart à vice-presidência. Esse suposto apoio brasileiro ao retorno de Perón seria uma "contraprestação normal de serviços, um auxílio de aliado, uma retribuição", em se considerando que após as eleições locais de 1950 o mandatário argentino prometera, por intermédio de Jango, ajuda armada para gara ntir a posse de Vargas. Por essa lógica, empossar Goulart acarretaria restaurar o peronismo na Argentina.

\section{O resultado das eleiçõese das investigações}

Nos primeiros dias de outubro de 1955, houve uma reviravolta no inquérito conduzido pelo general Maurell. Após entrevistar os principais nomes citados na carta Brandi e visitar Buenos Aires, Corrientes e Uruguaiana, ele ordenou a prisão de Alberto Jorge de Mestre Cordero e de Fernando Francisco Malfussi, dois argentinos que viviam no Rio de Janeiro e que haviam passado o documento a Lacerda. Soube-se depois que ambos confessaram sua falsificação.

Nesse momento, muito provavelmente, parecia claro a Lacerda que o horizonte dos próximos dias não lhe traria boas novas. A partir de então, ele delineou uma nova estratégia - a de chamar atenção para outros aspectos das relações entre Jango e o peronismo, que, em sua perspectiva, também mereceriam investigação.

À medida que passavam os dias, o resultado das urnas também foi ficando mais claro e confirmou os maus pressentimentos dos udenistas. A divulgação da carta Brandi pouco efeito tivera sobre o eleitorado, que sufragou a fórmula J-J. Kubistchek obteve 35,68\% dos votos, sendo seguido por Juarez Távora (30,27\%), Ademar de Barros (25,77\%) e Plínio Salgado (8,28\%). Na vice-presidência, João Goulart atingiu 44,25\%, com uma vantagem de apenas 200 mil votos em relação ao udenista Milton Campos (41,70\%).

Previsivelmente, a eleição do governador de Minas Gerais com pouco mais de um terço dos votos válidos provocou protestos da oposição, que já alegara a necessidade da maioria absoluta dos votos em 1950, quando Vargas obtivera "apenas" $48 \%$ dos votos válidos. Insistiase desta vez que os candidatos do PSD e do PTB haviam sido eleitos pelos comunistas e em conluio com os peronistas. No editorial intitulado "Dar posse aos gregórios é trair o Brasil", Lacerda (Tribuna da Imprensa, 10 out. 1955, p. 4), incansável, atacou: "Estamos, agora, diante de 
um fato: a eleição de Kubitschek e Jango, isto é, a volta dos gregórios, com uma ideologia de tipo peronista e uma aliança, que custará muito caro ao Brasil, com o Partido Comunista".

Embora a ala legalista da UDN tenha novamente levado o caso à Justiça Eleitoral, a possibilidade de aceitação da tese da maioria absoluta pelos juízes parecia remota mesmo para seus correligionários. Com isso, os adeptos civis e militares da "tese golpista" se fortaleceram. De acordo com Maria Victoria Benevides (1981, p. 98), essa ala contava com o apoio de setores mais radicais da Aeronáutica e da Marinha. Lacerda, em especial, criticou o que chamou de "legalismo palerma" (Tribuna da Imprensa, 1 set. 1955, p. 4) e assegurou que naquele momento essa posição funcionava como "pretexto para entregar o Poder aos inimigos do Brasil".

No dia 17 de outubro, Maurell, responsável pelo inquérito da carta Brandi, inesperadamente adiantou o resultado de uma nova análise grafológica feita pelo perito criminal brasileiro Antônio Carlos Villanova. Ele teve acesso a um número bem maior de padrões de assinatura de Brandi, colhidos na Argentina. Chefe da Seção Química do gabinete de Exames Periciais do Departamento Federal de Segurança Pública (DFSP), Villlanova não teve dúvida: a assinatura da carta fora falsificada (Tribuna da Imprensa, 18 out. 1955, p. 7). O inquérito, porém, continuaria.

Como era de se esperar, Lacerda passou a ser duramente acusado de falsário pela imprensa próxima ao PTB, como o jornal Última Hora. Inicialmente, ele assegurou que o general estava enganado e criticou sua precipitação em apresentar informações de um inquérito não concluído. Entre outras objeções, lembrou que ele próprio ainda não havia sido ouvido. Destacou que eram "mais importantes os fatos relatados na carta do que o próprio documento cuja autenticidade não podia comprovar". Lacerda (Tribuna da Imprensa, 20 out. 1955, p.1, 4) alegou ainda: "Pode ser a carta falsa - e verdadeiros serem os fatos e circunstâncias que ela menciona, ou aqueles que tenham com eles correlação". Também insistiu em lembrar que diversos eventos de anos anteriores sobre a "infiltração peronista" no Brasil deveriam ser examinados.

Após alguns dias de postergação, Lacerda prestou depoimento diante do general Maurell, em 27 de outubro de 1955. Levou consigo um calhamaço de 110 laudas datilografadas e 60 documentos. De a cordo com a Tribuna da Imprensa (28 out. 1955, p. 1, 4), o acontecimento teria chamado atenção de cerca de quinhentas pessoas, que se aglomeraram à porta do quartel da Polícia do Exército, no bairro do Andaraí. Diário Carioca (28 out. 1955, p. 1) estimou em duzentos presentes que aguardaram a saída do deputado e o teriam recebido com "uma mistura de vaias e aplausos".

O prolixo testemunho entregue a Maurell, bem ao estilo de Lacerda, foi publicado no dia seguinte (Tribuna da Imprensa, 29-30 out. 1955, p. 24). Firme em relação à sua linha de raciocínio, ele titulou-o "A Traição em Marcha" e fustigou: "A verdade sim! Mas a verdade 
inteira!". Na ocasião, Lacerda apresentou-se como vítima e alegou ter caído em uma "armadilha" que faria parte de "uma trama para glorificar João Goulart e procurar desmoralizá-lo [...]” (Tribuna da Imprensa, 28 out. 1955, p. 1, 4). Conformado com a conclusão a respeito da falsidade da carta, eximiu-se de qualquer culpa: "Se o documento é falso, como se afigura, tenho a dizer que não o falsifiquei, não o mandei falsificar, não colaborei para sua falsificação" (Tribuna da Imprensa, 29-30 out. 1955, p. 3).

A autovanglorização e a tenta tiva de retratar sua atuação política como um sacrifício para salvar a nação, tão frequentes em seus discursos, também estiveram presentes. Ele escreveu: "Assumi um risco calculado, sem heroísmo algum, pois me parecia muito remoto. Mas este foi, afinal, o mais certo. Cabe-me suportá-lo sozinho".

Lacerda narrou que tivera os primeiros contatos com os dois "meliantes" argentinos responsáveis pela falsificação em junho de 1955. O primeiro, Fernando Malfussi, foi-lhe apresentado por um colega jornalista e dizia ter provas do contrabando de armas na fronteira. Em seguida, Malfussi lhe teria lhe introduzido Mestre Cordero, que se apresentou como antiperonista exilado e proprietário de grande patrimônio que fora bloqueado pelo governo platino. Alegou ser amigo de antiperonistas de destaque exilados no Uruguai que possuíam reconhecidas ligações com Lacerda.

Pouco depois, Cordero teria oferecido espontaneamente ao jornalista fluminense documentação que poderia "evitar a vitória do tipo brasileiro de peronismo". Ao contrário do esperado, não lhe falou em dinheiro em nenhum momento. Em contraste com sua versão inicial, Lacerda esclareceu no testemunho à justiça que a carta Brandi não fora apreendida. Cordero the teria confessado que a roubara deliberadamente do argentino Ignacio Pinedo, o suposto portador da missiva, ao conhecê-lo em um hotel no Rio de Janeiro.

Assim que tomou contato com a carta Brandi, o jornalista estranhou diversas inconsistências, a começar pela coincidência na data de sua expedição, 5 de agosto, o mesmo dia do atentado da rua Tonelero. Todavia, o material lhe despertou muito interesse e um problema de consciência, que foi resumido por ele nas seguintes palavras: "O peronismo avança; eu tenho uma carta para barrá-lo".

Antes de tornar pública a carta Brandi, Lacerda a teria mostrado a alguns amigos e autoridades, entre elas o coronel João Adil de Oliveira, chefe da $2^{\text {a }}$ Seção do Estado Maior. Este lhe exigiu uma denúncia formal para investigar mais profundamente o caso, o que não foi feito, de acordo com Lacerda, por recomendação de Cordero, que temia contato com a polícia local. Ao contrário do que veiculou Tribuna da Imprensa, que assegurou desde o início sua autenticidade, Lacerda teria reconhecido nessas conversas privadas iniciais "a possibilidade, embora remota, de ser falso o papel". 
Em seu depoimento, o jornalista adotou a estratégia de repetir à exaustão a denúncia de um conluio entre trabalhistas e peronistas. Astutamente, Lacerda entremeou explicações sobre as circunstâncias do aparecimento da carta Brandi com longas acusações nesse sentido. Sem provas cabais dessa relação, baseou-se em algumas ilações e suposições feitas a partir de longas citações de documentos e testemunhos de dezenas de diplomatas, militares e outros homens públicos brasileiros. Esses indícios foram apresentados como provas insofismáveis e deram o fio condutor à ideia de uma traição silenciosa ao país.

Dessa forma, manteve-se a estratégia de apontar a carta como ponto de partida para futuras investigações, e não o de chegada. Nas palavras dele: "A carta é falsa? Mas os crimes contra o Brasil existiram - e todos esses indícios os comprovam. Nada se vai fazer sobre eles? Não produzem consequências? Que é mais importante: a carta ou o crime?". Em outro trecho, ele acusou: "Sabendo que ela é falsa permanece o dado essencial: é falso que o sr. João Goulart seja peronista, tenha pactuado com o peronismo, e esteja, de braço dados com o comunismo, pronto a usar o Poder para peronizar o Brasil?".

Ao final, Lacerda acusou Cordero, principal responsável pela falsificação, de possuir ligações com Jango e com Vargas e de ter trabalhado como "provocador" a serviço do presidente argentino. Reafirmou sua posição de vítima e acusou o falsário argentino preso de estar "a serviço de terceiros, empenhado na minha desmoralização e na glorificação de João Goulart".

O Estado de S. Paulo, jornal paulistano de fortes ligações udenistas, saudou o longo depoimento de Lacerda como uma peça "capaz de ocasionar mudança radical no curso das investigações militares do inquérito" (Tribuna da Imprensa, 31 out. 1955, p.1). Não foi o que aconteceu. Na véspera do feriado de finados, o general Maurell tornou público o relatório final que concluía pela falsidade da carta Brandi. Contrariando os insistentes pedidos de Lacerda, a investigação centrou-se apenas na missiva e nos supostos eventos citados nela. Maurell tampouco recomendou novo inquérito para investigar as relações entre peronistas e trabalhistas. Questionado a respeito, redarguiu: "Coisas fora da época não me cabiam apurar" (Tribuna da Imprensa, 1 nov.1955, p. 1).

Alberto Jorge Mestre Cordero e Fernando Francisco Malfussi, dois argentinos que faziam jogo duplo politicamente e viviam, nas palavras do relatório, em "precaríssima situação financeira", foram, após confissão, presos e formalmente indiciados. $O$ primeiro já respondia no Brasil a processo por "crime de estelionato e defraudações várias". O segundo foi classificado por Maurell como um notório "vadio contumaz e cínico vigarista". Para Maurell, não havia indícios ou provas da participação de terceiros na qualidade de mandantes do crime.

Assim, Lacerda não foi formalmente acusado de falsificação. O general que liderou a investigação disse estar convicto de que o jornalista fluminense e outras pessoas que haviam 
utilizado a carta para objetivos políticos tinham sido realmente ludibriados pelos dois argentinos. No entanto, o relatório indicou que a dupla de falsários teria se aproveitado da ânsia desses grupos políticos, que buscavam avidamente documentos que comprovassem os boatos sobre relações escusas com o peronismo. Sem dar nome aos bois, Maurell criticou-os indiretamente por mau jornalismo, pois teriam apresentado provas "sem mesmo indagar as fontes de onde provinham e nem a idoneidade moral de quem as fornecia". Explicava o relatório:

Estimulados pela insistência e notória avidez com que certos grupos ligados à política partidária e a certos órgãos de imprensa, procuravam obter informes capazes de confirmar e, se possível, caracterizar os boatos, de há muito circulantes, sobre contrabando de armas na fronteira com a Argentina, além de outros relativos a apregoadas atividades de pessoas ligadas ao Governo Vargas junto a Perón e a seus adeptos - Cordero e Malfussi, cuja identidade de propósitos crescia dia a dia resolveram tirar partido da situação que atingira o seu clímax nos últimos meses que antecederam os comícios eleitorais de 3 de outubro último (Tribuna da Imprensa, 1 nov. 1955, p.3).

A partir de então, a avalanche de críticas e acusações contra Lacerda avolumou-se. O jornal paulistano sob direção da fa mília Mesquita apoiou firmemente o jornalista fluminense no caso da carta Brandi. Seguindo a linha da Tribuna da Imprensa, assegurou que "a autenticidade da carta pode ser discutida, mas o que não pode ser posto em dúvida é que o sr. Goulart e o ex-ditador [Perón] viviam em contato e que esses contatos facilitaram a remessa de armas da Argentina para o Brasil". Em um editorialintitulado "Peronismo e getulismo", $O$ Estado de S. Paulo (2 nov. 1955, p. 3) fustigou violentamente o político gaúcho: "Atos de trai ção não podem ficar impunes. Quando entram em jogo a vida de instituições e a própria independência do País a repressão contra os culpados deve ser implacável".

O Cruzeiro (12 nov. 1955, p. 116), revista ilustrada brasileira de maior tiragem, adotou uma postura bem mais comedida. Em sua coluna Política, perguntou: "Os erros de Lacerda prejudicam o golpe?". O artigo deixava clara a enorme influência do jornalista e deputado federal naquela grave crise política após as eleições, definida pelo magazine como o "processo revolucionário de que [Lacerda] se tornou um foco agressivo e o polo mais visível". No entanto, a revista de Assis Chateaubriand criticou duramente sua atuação no episódio da carta falsificada, classificando-a como "uma nova batalha perdida nessa guerra do udenismo contra o getulismo, da direita contra a esquerda". A coluna apontou que o líder conservador 
agira "com certa facilidade ao se deixar envolver até a intimidade por agentes escusos e misteriosos [...]".

Semelhante postura adotou $O$ Globo, diário vespertino de Roberto Marinho, que com frequência abria as portas de sua rádio a Lacerda. $O$ jornal disse estar convencido da inexistência de qualquer "intenção dolosa de nosso colega". Além disso, exaltou seu "espírito de sacrifício", sua "repulsa à corrupção" e criticou a "agressiva e injusta" campanha que se desencadeava sobre ele naquele momento por parte da imprensa e do Congresso. Todavia, censurou seus "excessos de temperamento" e creditou que esses o haviam levado, em algumas ocasiões, a "cometer graves erros de apreciação quanto a pessoas e fatos" (Apud DULLES, 1992, p. 219).

\section{O movimento de 11 de novembro de 1955}

Coincidentemente, no mesmo dia em que o general Maurell anunciou as conclusões do inquérito sobre a carta Brandi, um fato inesperado ampliou a crise política pós-eleições. No enterro do general Canrobert Pereira da Costa, que fora um dos principais líderes da pressão exercida sobre Vargas na crise de agosto de 1954, o coronel Jurandir Mamede, também antigetulista, elogiou o colega falecido e criticou abertamente a posse de Juscelino e Jango. Sob chuva torrencial, alegou que eles representavam a "vitória da minoria" e que sua posse confirmaria uma "indiscutível mentira democrática". Ao final da cerimônia, Mamede foi cumprimentado efusivamente por diversos líderes militares e civis. Entre eles, estava Carlos Luz (PSD-MG), um político de ligações com a ala golpista do udenismo e então presidente da Câmara dos Deputados (CARLONI, 2014, p. 131).

Um dos presentes na ocasião, o ministro da Guerra, Henrique Teixeira Lott, entendeu o pronunciamento como um claro ato de insubordinação. Legalista, Lott defendia o respeito à Constituição e a posse dos eleitos. Ele vinha atuando também no sentido de impedir qualquer pronunciamento político por parte de membros mais exaltados do Exército nos dois polos da pugna política.

O discurso de Mamede coadunava-se claramente com a pregação golpista que seduzia principalmente setores militares e vinha sendo tenazmente difundida por alguns políticos udenistas e jornais como Tribuna da Imprensa e O Estado de S. Paulo. O matutino paulistano, por exemplo, enalteceu em editorial os militares argentinos que haviam tomado recentemente o poder e banido o partido justicialista. No texto, republicado pela Tribuna da Imprensa, a hesitação e a negligência da caserna brasileira em interferir em momentos-chave, 
como o fim do Estado Novo e a crise que levou ao suicídio de Vargas, foram duramente criticadas. Alegando que os petebistas haviam obtido ilegalmente apoio dos comunistas, o jornal paulistano conclamou oficiais locais a agirem para terminar "o que têm tido escrúpulo em acabar" (Tribuna da Imprensa, 27 out. 1955, p. 4).

No entanto, nem todos os veículos de comunicação não alinhados à esquerda clamaram pelo golpe (CARLONI, 2014, p. 126). O Correio da Manhã, por exemplo, defendeu incisivamente a posse dos eleitos e atacou pesadamente naquele que havia sido um dos seus principais colunistas na década de 1940: "tudo em Carlos Lacerda é pequeno, mesquinho, desprezível [...]. De real nele, só a vaidade que atinge a paranoia e uma crueldade que vai até a fúria assassina. O seu ideal seria a provocação de suicídios semestrais" (Apud DULLES, 1992, p. 223).

Do mesmo modo, o apelo aos militares não seduziu a todos os udenistas. Ao contrário de Lacerda, uma parte significativa do seu partido iniciou uma batalha jurídica contra a posse de Kubistchek, sob alegação de fraude eleitoral em diversos pontos do país. Importantes líderes, como Afonso Arinos, também se posicionaram contra soluções que violassem a Constituição (DULLES, 1992, p. 225). Ironicamente, o próprio general Juarez Távora, candidato derrotado por Kubistchek, não aderiu ao coro pela intervenção militar.

Lacerda (Tribuna da Imprensa, 4 nov. 1955, p. 4), cada dia mais ousado, entendeu aquele instante como um momento crucial e veiculou um editorial conclamando os militares a agirem e executarem imediatamente a "revolução" para impedir a posse "desses dois aventureiros irresponsáveis". Em "A hora das Forças Armadas", alegou que o Brasil não tinha uma democracia de verdade, mas uma estrutura ilegal, em "adiantado sistema de decomposição" e no qual grande parte da "massa getulista" já estaria sob controle do Partido Comunista.

De volta à crise, o violento discurso do coronel Jurandir Mamede contra a posse dos eleitos acirrou ainda mais os ânimos. Rapidamente, o ministro da Guerra, Henrique Lott, solicitou ao presidente da República a punição de Mamede. No dia seguinte ao discurso, o presidente Café Filho teve um ataque cardíaco e foi substituído temporariamente pelo já citado presidente da Câmara dos Deputados, Carlos Luz. Dias depois, este informou a Lott que não puniria Mamede pelo discurso. A atitude culminou na renúncia do ministro da Guerra em protesto. A partir daí, os acontecimentos de aceleraram. Na madrugada de 11 de novembro, Lott, desconfiado de uma conspiração envolvendo parte da oposição civil e militar, mobilizou tropas e ocupou pontos-chave da capital federal.

Lacerda, Luz, Mamede, alguns ministros e oficiais emba rcaram rapidamente no cruzador Tamandaré e partiram, debaixo de tiros, em direção a Santos. Tinham a perspectiva, que se mostrou frustrada, de organizar a resistência. Em seguida, a Câmara dos Deputados votou o impedimento de Luz e empossou Nereu Ramos, vice-presidente do Senado, como novo presidente interino. Logo depois, o Congresso, com grande número de votos do PTB e PSD, 
aprovou o afastamento de Café Filho e declarou estado de sítio por trinta dias, condição prorrogada até a posse dos eleitos, que efetivamente ocorreu no final de janeiro de 1956.

Com a intervenção militar liderada por Lott, o prédio da Tribuna da Imprensa foi tomado por tropas e o diário não circulou por dois dias. Lacerda asilou-se na embaixada de Cuba, governada então pelo ditador Fulgêncio Batista. Durante um ano de exílio, o jornalista fluminense passou por Cuba, Estados Unidos e Portugal. Coincidentemente, outro exilado, de ideias políticas bem distintas, também encontrou refugio em um país da América Central naquele mesmo mês. Temendo pela sua segurança em solo paraguaio, Juan Domingo Perón mudou-se para o Panamá. Nas escalas que seu voo fez no Brasil, relutou em sair do avião.

Oito meses após a conclusão do inquérito da carta Brandi, o juiz Pedro Ribeiro de Lima, da $9^{\text {a }}$ Vara Criminal do Rio de Janeiro, condenou Alberto Jorge Mestre Cordero e Fernando Francisco Malfussi. O primeiro a três anos e o segundo a dois anos e dois meses de reclusão, ambos pelo crime de falsificação do documento. Os dois também receberam multas. Na sentença, o magistrado considerou que Lacerda havia agido dolosamente ao publicar um documento a respeito do qual tinha confessadamente dúvidas em torno de sua autenticidade. Ao agir dessa forma, teria assumido "o risco da produção do resultado" (A Noite, 21 jul. 1956, p. 10). De acordo com notícia da época, o juiz iria solicitar à Câmara dos Deputados permissão para indiciar o jornalista, que continuava em Portugal, licenciado das atividades parlamentares (Diário de Notícias, 21 jul. 1956, p. 3).

Em um depoimento concedido um mês antes de sua morte, em 1977, o próprio Lacerda recordou o episódio da carta Brandi. Definiu 1955 como o pior ano de sua vida (DULLES, 1992, p. 3). Eis algumas de suas impressões vinte e dois anos depois:

Em suma, foi um revés, um desastre para mim, um negócio! Verdadeiramente talvez um dos períodos mais terríveis da minha vida, quer dizer eu passar como cúmplice de um falsário. E foi horrível! Não tenho a menor ideia da intenção desse argentino [Fernando Malfussi]. Dinheiro não era. Nunca me falou em dinheiro. Esperei inclusive que ele falasse. Nunca falou em dinheiro. E assim como apareceu, sumiu. Nunca mais vi esse sujeito

(LACERDA, 1978, p. 106).

Para Lacerda, a revelação da falsidade da carta Brandi não apenas o desmoralizou temporariamente, mas sobretudo desacreditou o tema. Nos anos seguintes, enquanto as 
representações anticomunistas se fortaleciam no imaginário político, o antiperonismo perdeu espaço.

Cinco anos após a carta Brandi, Lacerda foi eleito governador da Guanabara. Nos anos posteriores, ele notabilizou-se como um dos principais articuladores civis da ruptura institucional ocorrida em $1964 .^{7}$ Como mostraram inúmeros estudos, às vésperas do golpe civil-militar, a principal acusação a recair sobre os ombros de João Goulart não era a de ser peronista, mas a de se aliar aos comunistas e de abrir as portas do país ao perigo vermelho.

\section{Considerações finais}

O episódio da carta Brandi, narrado aqui a partir do ponto de vista de alguns de seus protagonistas, é importante porque mostra pelo menos duas questões. A primeira delas é como uma parte da imprensa contraditoriamente foi fundamental para o desmoronamento progressivo das instituições democráticas, o que acabou se consolidando em 1964. Ao abrir espaço e apoiar, implícita ou explicitamente, políticos com apreço meramente retórico por esse sistema, como Carlos Lacerda, alguns setores da imprensa reforçaram, sem dúvida, suas trincheiras políticas. No entanto, acabaram por contribuir, a médio prazo, para o enfraquecimento da própria democracia.

Ainda que se possa apontar a baixa tiragem de Tribuna da Imprensa, parece ter ficado claro, por meio das fontes citadas ao longo do texto, que a influência de Carlos Lacerda ultrapassou em muito o seu próprio jornal. Apoiado por veículos de comunicação com alcance bem maior, como $O$ Estado de S. Paulo e $O$ Globo, o então deputado federal foi um dos atores principais de uma crise política que poderia, de fato, ter culminado em um golpe militar que teria impedido a posse de Kubitschek e Goulart. Assim, não se trata de um caso marginal de um político radical apoiado por uma parcela minoritária. Trata-se de alguém que contou com apoio de boa parte do establishment midiático do período.

O segundo ponto a ser destacado é a enorme força do imaginário antiperonista que, após ser construído por anos de repetidas notícias e boatos, estava muito presente nas ações políticas da época. Entrelaçado ao anticomunismo, esse imaginário, pautado por um mito conspiratório, guarda características peculiares que, após a queda de Perón e o desmascaramento da carta Brandi, acabaram parcialmente esquecidos pela historiografia.

\footnotetext{
${ }^{7}$ Curiosamente, Lacerda já havia sido indicado candidato à presidência da República pela UDN para as eleições seguintes, em 1965 (BENEVIDES, 1981, p. 130-131). Esse pleito, como se sabe, nunca se realizou A “ditadura temporária e pedagógica", defendida por ele com outros termos, seguiu rumos bem diferentes.
} 


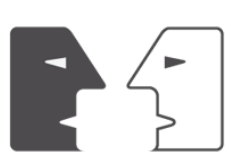

ANTÍTESES

Resgatar tais ideias é importante, entre outros motivos, para a compreensão da forma como o medo foi instrumentalizado ao longo da história política brasileira.

\section{Fonte Documental}

DUARTE FILHO, João. A carta do deputado. Coluna Tribuna Parlamentar. Tribuna da Imprensa, Rio de Janeiro, 23 set.1955. p. 3.

LACERDA, Carlos. Traição à vista. Tribuna da Imprensa, Rio de Janeiro, 10 ago. 1950. p. 4.

_ _ _ _ _. O Triunvirato. Tribuna da Imprensa, Rio de Janeiro, 9 dez. 1954. p. 1.

_. - _. Importação de armas na fronteira da Argentina. Tribuna da Imprensa, Rio de Janeiro, 8 jun. 1955. p. 1.

_. Jango prepara a guerra civil. Tribuna da Imprensa, Rio de Janeiro, 12 ago. 1955. p. 1.

_ - _ _ _. Apaziguamento e legalismo de Chambelain a Sobral Pinto. Tribuna da Imprensa, Rio de Janeiro, 1 set. 1955. p. 4.

. Eis a prova da traição de Jango. Tribuna da Imprensa, Rio de Janeiro, 17-18 set. 1955. p. 1.

_ _ _ _ _. Conluio contra o Brasil. Tribuna da Imprensa, Rio de Janeiro, 19 set. 1955. p. 1.

_ _ _ _ _ _. Termina aqui o caso do til. Tribuna da Imprensa, Rio de Janeiro, 23 set. 1955. p. 1.

_. Não, Ernani! Tribuna da Imprensa, Rio de Janeiro, 23 set. 1955. p. 1.

_. As razões de Juan Goulart. Tribuna da Imprensa, Rio de Janeiro, 23 set. 1955. p. 4.

. A Tribuna tem as provas da traição de Jango ao Brasil. Tribuna da Imprensa, Rio de Janeiro, 26 set. 1955. p. 1. [edição da manhã].

. Evitar que aconteça no Brasil a mesma desgraça da Argentina. Tribuna da Imprensa, Rio de Janeiro, 29 set. 1955. p. 4.

Na Câmara, o discurso de Perón sobre o ABC. Tribuna da Imprensa, Rio de Janeiro, 29 set. 1955 . p. 4. 
. Golpe de silêncio contra a divulgação da verdade. Tribuna da Imprensa, Rio de Janeiro, 30 set. 1955. p. 4.

_. Reflexões na hora de votar. Tribuna da Imprensa, Rio de Janeiro, 3 out. 1955. p. 1.

. A polícia argentina comprova: a Carta de Brandi é autêntica. Tribuna da Imprensa, Rio de Janeiro, 4 out. 1955. p. $1\left(1^{\circ}\right.$ caderno) e p. 8 ( $2^{\circ}$. Caderno).

4.

. Nenhuma violação à Lei Eleitoral. Tribuna da Imprensa, Rio de Janeiro, 4 out. 1955. p.

. Muito barulho por nada. Tribuna da Imprensa, Rio de Janeiro, 4 out. 1955. p. 1.

- Tropas peronistas na retaguarda para garantir a posse de Vargas. Tribuna da Imprensa, Rio de Janeiro, 4 out. 1955. p. 2.

. Por que Lott divulgou fatos do inquérito Jango-Peronismo. Tribuna da Imprensa, Rio de Janeiro, 7 out. 1955. p. 1.

_ _ _ _ _. Dar posse aos gregórios é trair o Brasil. Tribuna da Imprensa, Rio de Janeiro, 10 out. 1955. p. 4. (edição final).

_. Prometeu em 10 dias; revelou em 72 horas. Tribuna da Imprensa, Rio de Janeiro, 18 out. 1955. p. 7.

A carta é o ponto de partida e não ponto final. Tribuna da Imprensa, Rio de Janeiro, 20 out. 1955. p. $1,4$.

_. Que a lei se cumpra! Tribuna da Imprensa, Rio de Janeiro, 27 out. 1955. p. 4.

LACERDA investe contra Maurell: 'Desmoraliza a mim e a Aeronáutica'. Diário Carioca, Rio de Janeiro, 28 out. 1955. p. 1.

LACERDA, Carlos. Ameaçado de morte na presença de Jango. Tribuna da Imprensa, Rio de Janeiro, 28 out. 1955. p. 1, 4.

. A Traição em Marcha. Tribuna da Imprensa, Rio de Janeiro, 29-30 out. 1955. 24 p. (Suplemento especial). (Acervo Carlos Lacerda - UNB).

O depoimento de Lacerda modificará o inquérito. Tribuna da Imprensa, Rio de Janeiro, 31 out. 1955. p. 1.

. Maurell apurou apenas uma parte da verdade. Tribuna da Imprensa, Rio de Janeiro, 1 nov. 1955. p. 1. 
. Maurell sepulta o inquérito na véspera de finados. Tribuna da Imprensa, Rio de Janeiro, 1 nov.1955. p. 3.

_ _ _ _ _ . Peronismo e getulismo. Tribuna da Imprensa, Rio de Janeiro, 3 nov. 955. p. 3.

_. A hora das Forças Armadas. Tribuna da Imprensa, Rio de Janeiro, 4 nov. 1955. p. 4.

_ _ _ _ . . Os erros de Lacerda prejudicam o golpe? O Cruzeiro, Rio de Janeiro, 12 nov. 1955.

_ - _ _ . . Condenados Cordero e Malfussi. A Noite, Rio de Janeiro, 21 jul. 1956. p. 10.

- _ _ _ _. Concluiu o juiz ter agido o deputado 'dolosamente' no caso da Carta Brandi. Diário de Notícias, Rio de Janeiro, 21 jul. 1956. p. 3.

\section{Referências}

BENEVIDES, Maria Victoria de Mesquita. A UDN e o udenismo - ambiguidades do liberalismo brasileiro (1945-1965). Rio de Janeiro: Paz e Terra, 1981.

CAPElAto, Maria Helena. Multidões em Cena: Propaganda Política no Varguismo e no Peronismo. 2a edição. São Paulo: Editora UNESP, 2008.

CARLONI, Karla Guilherme. Marechal Lott, a opção das esquerdas: uma biografia política. Rio de Janeiro: Garamond, 2014.

CAVLAK, Iuri. A política externa brasileira e a Argentina Peronista (1946-1955). São Paulo: Annablume, 2008.

CHARTIER, Roger. O mundo como representação. Estudos Avançados, São Paulo, v. 5, n. 11, abr. 1991.

DULLES, John W. Foster. Carlos Lacerda: a vida de um lutador (1914-1960). Rio de Janeiro: Nova Fronteira, 1992. v.1.

GIRARDET, Raoul. Mitos e Mitologias Políticas. Tradução de Maria Lúcia Machado. São Paulo: Companhia das Letras, 1987. p. 25-62.

LACERDA, Carlos. Depoimento. Rio de Janeiro: Nova Fronteira, 1978.

MENDONÇA, Marina Gusmão de. O demolidor de presidentes. 2. ed. São Paulo: Códex, 2002. 


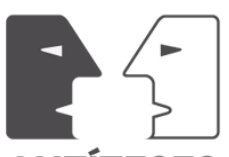

ANTÍTESES

PERÓN, Juan Domingo. La hora de los pueblos. Buenos Aires: Norte, 1968.

RIBEIRO, Ana Paula Goulart. Imprensa e história no Rio de Janeiro dos anos 1950. Rio de Janeiro: E-papers, 2007.

SKIDMORE, Thomas. Brasil: de Getúlio a Castelo. 7. ed. Rio de Janeiro: Paz e Terra, 1982.

Recebido em 06/03/2107

Aprovado em 26/06/2017 